University of Nebraska - Lincoln

DigitalCommons@University of Nebraska - Lincoln

\title{
Short Report: Hepatitis B Infection and Severe Plasmodium Falciparum Malaria in Vietnamese Adults
}

\author{
Mazie J. Barcus \\ U.S. Naval Medical Research Unit \#2 \\ Tran T. Hien \\ Cho Quan Hospital \\ Nicholas J. White \\ Mahidol University \\ Kanti Laras \\ U.S. Naval Medical Research Unit \#2 \\ Jeremy Farrar \\ Cho Quan Hospital \\ See next page for additional authors
}

Follow this and additional works at: https://digitalcommons.unl.edu/usnavyresearch

Barcus, Mazie J.; Hien, Tran T.; White, Nicholas J.; Laras, Kanti; Farrar, Jeremy; Schwartz, Ira K.; Corwin, Andrew; and Baird, J. Kevin, "Short Report: Hepatitis B Infection and Severe Plasmodium Falciparum Malaria in Vietnamese Adults" (2002). U.S. Navy Research. 53.

https://digitalcommons.unl.edu/usnavyresearch/53

This Article is brought to you for free and open access by the U.S. Department of Defense at DigitalCommons@University of Nebraska - Lincoln. It has been accepted for inclusion in U.S. Navy Research by an authorized administrator of DigitalCommons@University of Nebraska - Lincoln. 


\section{Authors}

Mazie J. Barcus, Tran T. Hien, Nicholas J. White, Kanti Laras, Jeremy Farrar, Ira K. Schwartz, Andrew Corwin, and J. Kevin Baird 


\title{
SHORT REPORT: HEPATITIS B INFECTION AND SEVERE PLASMODIUM FALCIPARUM MALARIA IN VIETNAMESE ADULTS
}

\author{
MAZIE J. BARCUS, TRAN T. HIEN, NICHOLAS J. WHITE, KANTI LARAS, JEREMY FARRAR, IRA K. SCHWARTZ, \\ ANDREW CORWIN, AND J. KEVIN BAIRD \\ U.S. Naval Medical Research Unit 2, Jakarta, Indonesia; Center for Tropical Diseases, Ho Chi Minh City, Vietnam; \\ Rollins School of Public Health, Emory University, Atlanta, Georgia
}

\begin{abstract}
We investigated the prevalence of infection with hepatitis B virus among adult Vietnamese patients hospitalized for severe Plasmodium falciparum malaria. Sera from patients admitted with severe malaria in Ho Chi

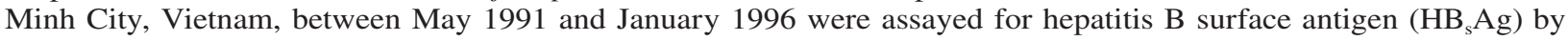
a commercial enzyme-linked immunosorbent assay kit. The overall prevalence of $\mathrm{HB}_{\mathrm{s}} \mathrm{Ag}$ was $23.77 \%$ (77 of 324). This was higher than reported estimates of prevalence in the general catchment population for the study hospital (mean, 9.8\%; range, 9-16\%). No association was found between risk of death caused by severe malaria and $\mathrm{HB}_{\mathrm{s}} \mathrm{Ag}$. Patients admitted with cerebral malaria had a slightly greater risk of registering positive for $\mathrm{HB}_{\mathrm{s}} \mathrm{Ag}$ (relative risk, $1.28 ; 95 \%$ confidence interval, 1.04-1.58) relative to other manifestations of severe malaria. Chronic infection with hepatitis $\mathrm{B}$ virus may be a risk factor for severe malaria.
\end{abstract}

Despite remarkable achievements in reducing malaria mortality, malaria remains the most common cause of morbidity and mortality in Vietnam. Of the 71.6 million population, 41.9 million are at risk for malaria; 15 million live in malariaendemic areas. ${ }^{1}$ The majority of people with malaria are not admitted to the hospital. Instead, they receive oral therapy on an outpatient basis. People who develop severe malaria and enter the hospital represent a minority of patients.

This report examines the association of infection with hepatitis B and severe malaria and the impact of that factor on survival. Hepatitis B, a double-stranded DNA virus of the hepadnoviridae family, infects $15 \%$ of people in Southeast Asia. ${ }^{2}$ Globally, $>2$ billion people are infected; 350 million of which are asymptomatic carriers of the virus. ${ }^{3}$ The infection kills $>1$ million carriers annually, with mortality generally associated with complications of cirrhosis, hepatocellular carcinoma, and, rarely, fulminant liver failure during acute infection. ${ }^{4,5}$

Coendemic falciparum malaria and acute hepatitis B occur through much of Southeast Asia, Africa, and the tropical Americas. Both diseases represent key threats to public health. To our knowledge, large studies evaluating the effect of acute hepatitis B infection on risk of severe disease and death caused by falciparum malaria have not been reported. We hypothesized that acute hepatitis B may exacerbate the risk of sequelae with infection by Plasmodium falciparum. By assaying for hepatitis B surface antigen, a marker for active infection, among patients admitted to hospital in Vietnam and enrolled into a treatment trial for severe malaria, we were able to test this hypothesis. ${ }^{6}$

Between May 1991 and January 1996, a randomized, double-blind controlled trial was conducted by Hien and others ${ }^{6}$ to compare artemether to quinine for the treatment of severe malaria in Vietnamese adults. The study took place in a research ward at the Center for Tropical Diseases in Ho Chi Minh City, Vietnam. Severe malaria was defined as having one or more of the following: cerebral malaria (Glasgow Coma Scale $<11$ ), anemia (hematocrit $<20 \%$ ) with a parasite count $>100,000 / \mu \mathrm{L}$, jaundice (serum bilirubin $>2.5$ $\mathrm{mg} / \mathrm{dL}$ ) with a parasite count $>100,000 / \mu \mathrm{L}$, renal impairment (urine output $<400 \mathrm{~mL} / 24 \mathrm{hr}$ and serum creatinine $>$ $3 \mathrm{mg} / \mathrm{dL}$ ), hypoglycemia (blood glucose $<40 \mathrm{mg} / \mathrm{dL}$ ), hy- perparasitemia $(>10 \%$ ), or shock (systolic blood pressure $<80 \mathrm{~mm} \mathrm{Hg}$ with cool extremities). This definition of severe malaria includes 2 criteria considered supporting by the World Health Organization (WHO), hyperparasitemia and jaundice, and does not include 5 criteria included by WHO: respiratory distress, repeated convulsions, spontaneous bleeding, acidosis, and hemoglobinuria.

Inclusion criteria included the following: age $>14$ years, not in the first trimester of pregnancy, no intravenous drug abuse, and receipt of $<3 \mathrm{~g}$ quinine or 2 doses of any artemisinin derivatives in the previous $48 \mathrm{hr}$. Eligible subjects were enrolled after informed consent was obtained from the patients or their guardians. ${ }^{6}$ A total of 560 patients were enrolled and randomly assigned to receive either artemether or quinine dihydrochloride intramuscularly, according to the regimens described by Hien and others. ${ }^{6}$ Artemether proved as safe and effective as quinine.

Assessable sera samples were obtained from 326 of these subjects. Samples from the remaining subjects were exhausted in a battery of other tests. Samples were collected by disposable syringe, centrifuged, serum aspirated, and maintained for the first 3 months at $-20^{\circ} \mathrm{C}$. Samples were then transferred to a $-70^{\circ} \mathrm{C}$ freezer and stored at the Institute for Clinical Research in Tropical Medicine, Hanoi, Vietnam. The U.S. Naval Medical Research Unit 2 in Jakarta, Indonesia, analyzed the samples with the commercially available Auszyme monoclonal diagnostic kit for the detection of hepatitis B surface antigen in serum or plasma (Abbott Laboratories, Singapore) according to the manufacturer's instructions.

Results were expressed as means or frequencies of positive and negative results and were analyzed by the unpaired Student's $t$-test or by the Mantel-Haenszel test. The chisquare test was used to assess differences in proportions. $P$ $\leq 0.05$ was considered statistically significant. Logistic regression was used to evaluate the relationship between several potential confounders and death from severe malaria. Analysis was carried out by SPSS version 8.0 (SPSS, Chicago, IL) and Epi Info version 6 (Centers for Disease Control and Prevention, Atlanta, GA).

The mean age of severe malaria subjects was 33 years (standard deviation, 13), with a range of 15-78 years. Se- 
TABLE 1

Characteristics of patients of admission according to hepatitis B status

\begin{tabular}{|c|c|c|c|}
\hline Characteristic & $\mathrm{HB}_{\mathrm{s}} \mathrm{Ag}$ positive & $\mathrm{HB}_{\mathrm{s}} \mathrm{Ag}$ negative & $P$ value \\
\hline \multicolumn{4}{|l|}{ Age (years) } \\
\hline Median & 29 & 30 & 0.55 \\
\hline Range & $15-71$ & $15-78$ & \\
\hline $\operatorname{Sex}(\%$ male $)$ & $57 / 77(74.0)$ & $182 / 247(73.7)$ & 0.95 \\
\hline Pregnant $(\%)$ & $3 / 77$ (3.9) & $11 / 247(4.6)$ & 0.83 \\
\hline Intravenous drug use $(\%)$ & $0 / 76(0.0)$ & $2 / 236(0.8)$ & 0.42 \\
\hline Treatment regimen (\% receiving quinine) & $45 / 77(58.4)$ & $121 / 247(49.0)$ & 0.15 \\
\hline Cerebral malaria* $(\%)$ & 49/77 (63.6) & $122 / 246(49.6)$ & 0.03 \\
\hline Shock $\dagger(\%)$ & $12 / 77(15.6)$ & $28 / 247(11.3)$ & 0.32 \\
\hline Jaundice $\$(\%)$ & $31 / 73(42.5)$ & $126 / 240(52.5)$ & 0.13 \\
\hline Renal failure§ (\%) & $17 / 77(22.1)$ & $76 / 243(31.3)$ & 0.12 \\
\hline Severe anemiađI $(\%)$ & $2 / 77(2.6)$ & $18 / 245(7.3)$ & 0.13 \\
\hline Fever\# $(\%)$ & $67 / 77(87.0)$ & $194 / 247(78.5)$ & 0.10 \\
\hline Transfusion $(\%)$ & $13 / 77(16.9)$ & $63 / 246(25.6)$ & 0.12 \\
\hline Pulmonary syndrome** (\%) & 26/77 (33.8) & $96 / 247(33.1)$ & 0.42 \\
\hline Convulsions & 8/77 (10.4) & $23 / 247(9.3)$ & 0.78 \\
\hline
\end{tabular}

* Glasgow Coma Scale $<11$.

$\dagger$ Systolic blood pressure $<80 \mathrm{~mm} \mathrm{Hg}$ with cool extremities.

$\ddagger$ Serum bilirubin $>3.0 \mathrm{mg} / \mathrm{dL}$

$\ddagger$ Serum bilirubin $>3.0 \mathrm{mg} / \mathrm{dL}$.
$\S$ Serum creatinine $>3.0 \mathrm{mg} / \mathrm{dL}$.

§ Serum creatinine $>3.0$

II Hematocrit $<15 \%$.
\# Temperature $\geq 37.5^{\circ} \mathrm{C}$.

** Any one of the following: acute respiratory failure, pulmonary distress, or pulmonary edema.

$\mathrm{HB}_{\mathrm{s}} \mathrm{Ag}=$ hepatitis B surface antigen.

roprevalence of hepatitis B surface antigen ( $\mathrm{HB}_{\mathrm{s}} \mathrm{Ag}$ ) was $77 /$ $324(23.8 \%)$. The death rate among patients with severe malaria was $47 / 323(14.6 \%)$. Table 1 lists the demographic and clinical characteristics of subjects, comparing these between those positive and negative for $\mathrm{HB}_{\mathrm{s}} \mathrm{Ag}$. The only statistically significant difference between $\mathrm{HB}_{\mathrm{s}} \mathrm{Ag}$-positive and -negative subjects was in frequency of cerebral malaria: 64 versus $50 \%$ $(P=0.03)$. The relative risk of cerebral malaria with $\mathrm{HB}_{\mathrm{s}} \mathrm{Ag}$ was 1.28 (95\% confidence interval $[\mathrm{CI}], 1.04-1.58, P=$ 0.03). The frequency of jaundice, renal failure, severe anemia, and the necessity of transfusion were all lower among $\mathrm{HB}_{\mathrm{s}} \mathrm{Ag}$-positive subjects, but these differences were not statistically significant.

Table 2 lists the death rate stratified by $\mathrm{HB}_{\mathrm{s}} \mathrm{Ag}$ status. $\mathrm{HB}_{\mathrm{s}} \mathrm{Ag}$ positivity carried no elevated risk of death compared with patients without evidence of hepatitis B infection. Multivariate logistic regression analysis controlling for age, sex, pregnancy, and treatment regimen revealed no association between a higher risk of death and $\mathrm{HB}_{\mathrm{s}} \mathrm{Ag}$ positivity. Age was modeled as a categorical variable with the following groups: $<25$ years, $26-35$ years, $36-50$ years, and $>50$ years. The adjusted odds ratio $(95 \% \mathrm{CI})$ was $0.95(0.44-2.00)$, similar to the crude odds ratio of 0.99 (0.45-2.16). The sample of analyzable sera in this study would have detected $a \geq 13 \%$ difference in incidence of death with $80 \%$ power. The analysis thus reveals that $\mathrm{HB}_{\mathrm{s}} \mathrm{Ag}$ in serum at the time of admission for severe malaria was not a significant risk factor for death as an outcome for the treatment regimens applied.

$\mathrm{HB}_{\mathrm{s}} \mathrm{Ag}$, the outer coat protein of the virus, is a marker for acute infection or a chronic carrier state. $\mathrm{HB}_{\mathrm{s}} \mathrm{Ag}$ is detectable for 2-15 weeks after exposure and then disappears in $\sim 90 \%$ of people infected during convalescence. In the remaining $10 \%, \mathrm{HB}_{\mathrm{s}} \mathrm{Ag}$ does not clear. These people become chronic carriers. The patients positive for $\mathrm{HB}_{\mathrm{s}} \mathrm{Ag}$ in this study were not suffering acute hepatitis, but were presumably nearly all chronic carriers, although we cannot exclude with certainty that some patients may have had a resolving acute infection. The cross-sectional prevalence of $\mathrm{HB}_{\mathrm{s}} \mathrm{Ag}$ (e.g., at admission to hospital with severe malaria) includes those recovering from acute infection and the cumulative proportion of chronic carriers in the population.

The prevalence of $\mathrm{HB}_{\mathrm{s}} \mathrm{Ag}$ in subjects with severe malaria was $23.77 \%$ (77/324), higher than in cross-sectional estimates from the general adult population of the region. The study by Kakumu and others represents an exception to this as the population surveyed included children (mean age, 28 years; range, 2-81 years). ${ }^{2}$ Table 3 summarizes measurements of the prevalence of $\mathrm{HB}_{\mathrm{s}} \mathrm{Ag}$ in populations from which the severe malaria patients were drawn and compares these to $\mathrm{HB}_{\mathrm{s}} \mathrm{Ag}$ prevalence in those patients. In all instances, the prevalence among subjects with severe malaria was significantly higher $(P<0.001)$. Measurements of the prevalence of $\mathrm{HB}_{\mathrm{s}} \mathrm{Ag}$ in the general population ranged $9-16 \% .^{7,8}$ The lower range, 3.1-5.7\%, occurred among residents of rural areas of Ho Chi Minh City. We considered 9.8\% $\mathrm{HB}_{\mathrm{s}} \mathrm{Ag}$ positivity reported from the large study of Tran and others ${ }^{8}$ a surrogate control for the severe malaria cases we evaluated.

TABLE 2

Assessment of outcome

\begin{tabular}{cccc}
\hline Variable & $\begin{array}{c}\mathrm{HB}_{\mathrm{s}} \mathrm{Ag} \text { positive } \\
(\%)\end{array}$ & $\begin{array}{c}\mathrm{HB}_{\mathrm{s}} \mathrm{Ag} \text { negative } \\
(\%)\end{array}$ & $\begin{array}{c}\text { Relative risk } \\
(95 \% \text { confidence interval) }\end{array}$ \\
\hline Prevalence of death & $11 / 76(14.5)$ & $36 / 247(14.6)$ & $0.99(0.53-1.85)$ \\
\hline Relative risk is for the $\mathrm{HB}_{\mathrm{s}} \mathrm{Ag}$-positive group. Groups were compared via the Mantel-Haenszel test. $\mathrm{HB}{ }_{\mathrm{s}} \mathrm{Ag}=$ hepatitis B surface antigen.
\end{tabular}


TABLE 3

History of $\mathrm{HB}_{\mathrm{s}} \mathrm{Ag}$ prevalence studies in Ho Chi Minh City, Vietnam

\begin{tabular}{|c|c|c|c|}
\hline Date of study & $\begin{array}{l}\text { Population of } \\
\text { Ho Chi Minh City }\end{array}$ & $\begin{array}{l}\text { Prevalence of } \mathrm{HB}_{\mathrm{s}} \mathrm{Ag} \\
(\%)\end{array}$ & $\begin{array}{c}\text { Chi-Square test statistic* } \\
(P \text { value })\end{array}$ \\
\hline 1996 & Rural area ${ }^{2}$ & $5.7(51 / 890)$ & $81.91(<0.001)$ \\
\hline \multirow[t]{3}{*}{1993} & Subpopulations ${ }^{7}$ & & \\
\hline & Overall & $10.5(64 / 610)$ & $29.09(<0.001)$ \\
\hline & Range & $8-14 \%$ & \\
\hline \multirow{4}{*}{$\begin{array}{c}1992 \\
1989-1991\end{array}$} & Blood donors 9 & $3.1(15 / 491)$ & $83.61(<0.001)$ \\
\hline & Subpopulations $^{8}$ & & \\
\hline & Overall in normal population $\dagger$ & $9.8(3,837 / 39,080)$ & $69.87(<0.001)$ \\
\hline & Range in normal population $\dagger$ & $9-16 \%$ & \\
\hline
\end{tabular}

* Comparing the prevalence in patients with severe malaria with each population. $\mathrm{HB}_{\mathrm{s}} \mathrm{Ag}$ = hepatitis $\mathrm{B}$ surface antigen

$\dagger$ Excluding intravenous drug abusers, patients with hepatitis, and patients with liver cancer.

Excluding intravenous drug abusers, hepatitis patients, and liver cancer patients yielded a population of 39,080 subjects, closely approximating the population from which our sample was drawn. Using that estimate of normal risk of $\mathrm{HB}_{\mathrm{s}} \mathrm{Ag}$ positivity, the odds ratio for the likelihood of $\mathrm{HB}_{\mathrm{s}} \mathrm{Ag}$ positivity in patients with severe malaria versus the normal population was 2.9 (95\% CI, 2.19-3.73, $P<0.0001)$. Obviously, a prospective case control study would have provided a more accurate estimate of this ratio. Finally, malaria tends to be a rural disease in Vietnam, where prevalence of hepatitis B is relatively low. If the severe malaria patients at Ho Chi Minh Hospital came predominately from rural areas with relatively low rates of hepatitis $B$, the relative risk of concurrent events would be considerably higher. Therefore, we considered the 2.9 odds ratio of $\mathrm{HB}_{\mathrm{s}} \mathrm{Ag}$ in severe malaria patients versus the normal population to be a conservative indirect estimate of elevated risk of severe malaria with hepatitis B infection. This finding warrants studies that directly measure the risk of severe malaria with hepatitis B disease.

Our analysis, which was based on samples collected in the setting of a therapeutic trial, suggests that acute hepatitis B infection may exacerbate falciparum malaria, causing an elevated risk of admission to the hospital for severe malaria. The analysis lacked carefully selected controls for the severe malaria cases and applied a relatively crude classification of hepatitis B disease. In addition, it is possible that some sampling bias existed because sera samples were not available from all patients. Last, because this study included only adult subjects, the conclusions cannot be automatically extrapolated to children. The findings nonetheless point to the possibility of an interaction between these diseases that may increase the risk of morbidity and mortality for the many millions of people exposed to endemic risk of both infections. The mechanism of this apparent increase in susceptibility is not known. Perhaps chronic hepatitis B carriers are less efficient at limiting parasite multiplication. There was no suggestion that hepatitis B carriers were older or more likely to come from malaria endemic areas, which might imply a failure to develop specific protective immunity. Understanding this relationship may help refine strategies intended to diminish disease and death caused by malaria.

Acknowledgments: The authors acknowledge Andy Tucker for his thoughtful and timely reviews of the statistics. The views and opinions are those of the authors and do not represent those of the U.S.
Navy or Department of Defense. Mazie Barcus completed this work as part of a master's thesis for Emory University.

Financial support: Financial support was granted by the Wellcome Trust, UK (T.T.H., N.J.W., J.F.).

Authors' addresses: Mazie J. Barcus, Kanti Laras, Andrew Corwin, and J. Kevin Baird, American Embassy Jakarta, Unit 8132, NAMRU2, FPO AP 96520-8132. Tran T. Hien and Jeremy Farrar, Center for Tropical Diseases, Cho Quan Hospital, 190 Ben Ham Tu-Q.5, Ho Chi Minh City, Vietnam. Nicholas J. White, Faculty of Tropical Medicine, Mahidol University, 420/6 Rajvithi Road, Bangkok, 10400, Thailand. Ira Schwartz, Rollins School of Public Health at Emory University, International Health Department, 1518 Clifton Road NE, Atlanta, GA 30322.

Reprint requests: Commanding Officer, U.S. Naval Medical Research Unit 2, American Embassy Jakarta, FPO AP 96520-8132, USA, to the attention of the Publications Office.

\section{REFERENCES}

1. World Health Organization, 2000. Roll Back Malaria action at the country level: country updates October 1998-June 2000. WHO/CDS/RBM 2000(24): 78.

2. Kakumu S, Sato K, Morishita T, Trinh KA, Nguyen HB, Banh VD, Do HC, Nguyen HP, Nguyen VT, Le TT, Yamamoto N, Nakao H, Isomura S, 1998. Prevalence of hepatitis B, hepatitis $\mathrm{C}$, and $\mathrm{GB}$ virus $\mathrm{C} /$ hepatitis $\mathrm{g}$ virus infections in liver disease patients and inhabitants in Ho Chi Minh, Vietnam. $J$ Med Virol 54: 243-248.

3. EPI WHO, 1996. Hepatitis B Vaccine-Making Global Progress. Update 31. Geneva: Expanded Programme on Immunization, World Health Organization.

4. Maguire JD, 1998. Infectious hepatitis. Gates RH, ed. Infectious Disease Secrets. Philadelphia: Hanley and Belfus, 218-225.

5. World Health Organization, 2001. Hepatitis B Fact Sheet WHO/ 204. Revised October 2000. Available at: http://www.who.int/ inf-fs/en/fact204.html (site address confirmed 8 August 2001).

6. Hien TT, Day NP, Nguyen HP, Nguyen TH, Tran TH, Pham PL, Dinh XS, Ly VC, Ha V, Waller D, Peto TE, White NJ, 1996. A controlled trial of artemether or quinine in Vietnamese adults with severe falciparum malaria. $N$ Engl J Med 355: 76-83.

7. Nakata S, Song P, Duc DD, Nguyen XQ, Murata K, Tsuda F, Okamoto H, 1994. Hepatitis C and B virus infections in populations at low or high risk in Ho Chi Minh and Hanoi, Vietnam. J Gastroenterol Hepatol 9: 416-419.

8. Tran VB, Buu M, Nguyen TM, Morris GE, 1993. Hepatitis B in Ho Chi Minh City, Viet Nam. Trans $R$ Soc Trop Med Hyg 87: 262.

9. Song P, Duc DD, Hien B, Nakata S, Chosa T, Watanabe J, Tsuda F, Murata K, Okamoto H, 1994. Markers of hepatitis C and B virus infections among blood donors in Ho Chi Minh City and Hanoi, Vietnam. Clin Diagn Lab Immunol 1: 413-418. 